岡山医誌（1991） 103，611～617

\title{
トリクロルエチレン代謝および 尿中代謝産物の保存に関する研究
}

\author{
第 2 編 \\ トリクロルエチレンをマウスに投与後の臓器内分布
}

岡山大学医学部公衆衛生学講座（指導：緒方正名教授）

後村達也

(平成 3 年 2 月 27 日受稿)

Key words : トリクロルエチレン, 半隇期, 臓器内分布, マウス

\section{緒言}

トリクロルエチレンは, 分子式 $\mathrm{CCl}_{2}: \mathrm{CHCl}$ で, 無色, 揮発性の液体であり, 刺激的甘味の 臭気を有する有機溶哓である．その沸点は $87^{\circ} \mathrm{C}$ であるが，不燃性，非爆発性の特長がある，以 前はドライクリーニングや吸入麻酔剂としても 用いられていた。

現在,トリクロルエチレンはメッキ・塗装前 の金属の脱脂剂として，また溶剤として広範囲 に使用されている。トリクロルエチレンの取り 扱い作業者の健康管理のための環境作業場の許 容濃度を ACGIH，TLV-TWA（時間荷重平均 值) は50pmで STEL, short time limit.（15分 以内の平均值200ppr）に規制している.

一方, ACGIH は, トリクロルエチレンの「従 来」の TLV-TWA と共に, その補助手段とし て，1984年以来，一般代表的有機溶剂に関する 作業者の生体試料中の測定物質についての生物 学的暴露指数 (Biological exposure indices) BEIの勧告を行った。我国において労働省が平 成元年10月よりトリクロルエチレン作業者全貝 の尿中トリクロル酸とトリクロルエタノールの 測定を義務づけた。

即方, ACGIHの BEI は呼気中のトリクロル エチレン，血中のトリクロルエチレン，および, 尿中代謝産物濃度について勧告した。

一般に生体内に入った薬物は, 主として循環
血流によって生体各部の睵器および組織に運ば れて分布する。そしてその組織内濃度に影響を 及ばす因子には，薬物代謝，排泄または組織内 蓄積性などがある。

近年, 薬物の生体での推移を時間と生体およ び薬物の組み合わせごとに変化する現象論的定 数を使用して算出しようとする試みが発達して きている。

高原 ${ }^{1,2)}$ は 1，1，1-或は 1，1，2-トリク口ロ エタン投与後の臟器内分布の差異について報告 している。また，嶋田31は，モノクロロベンゼン をラットに投与後の藏器内分布についての報告 を行っている。神谷4)は，放射性トルエンをマウ スに投与した後の蔵器内分布について報告して いる。

そこで今回，一般的に広く使用されているト リクロルエチレンをマウスに吸入きせた後の各 組織および血液中濃度の時間的経過を測定しそ れから初期分配相と代謝排泄相の 2 相を想定し， また， 2 相についての生物学的半減期を求め, さらに排泄速度定数を算出する試みを行った。

\section{対象と方法}

1. 実験動物； 8～12週令の dd 系雌マウス （体重20２3ｇ）を用いた動物は温度調節した 室内で飼育し，飼料としてオリエンタル固型飼 料を与之，水は水吞瓶から自由に与之た。

2. 暴露；高原 ${ }^{1,2)}$ の使用した暴露装置（Fig. 


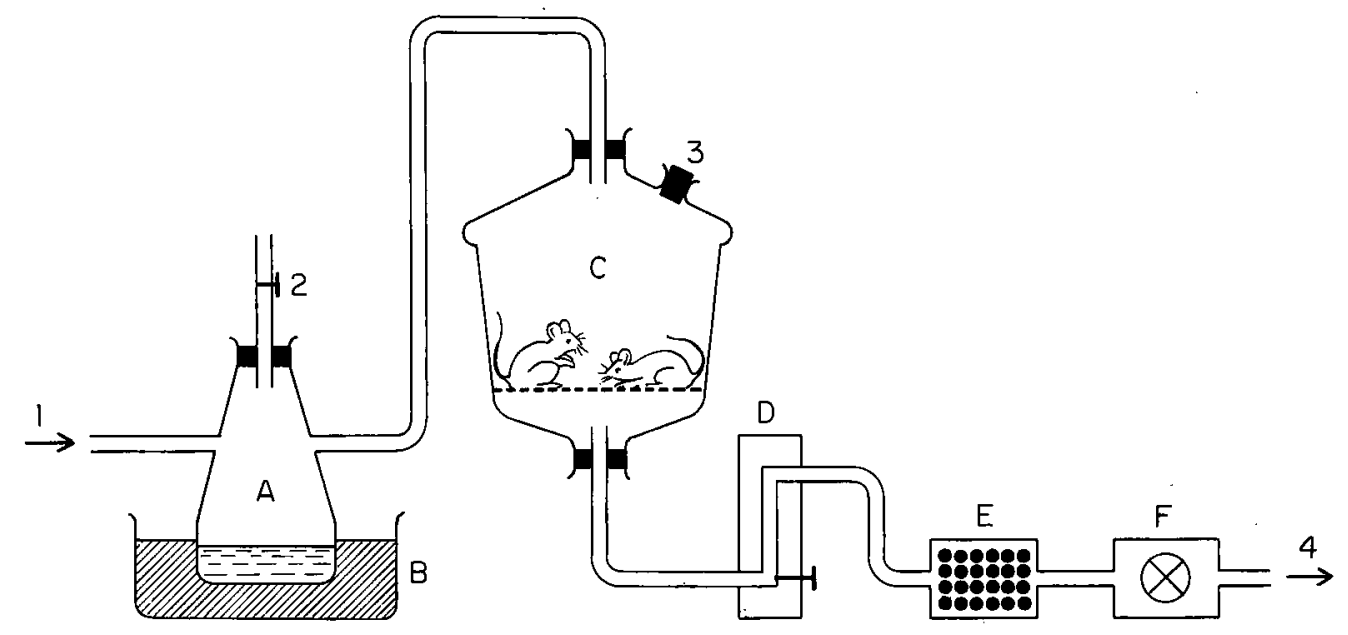
A. gas qenerator B. water both with temperature requlator
C. exposure chamber
D. flow meter $E$. charcoal $F$. suction pomp
1 . in let 2. control cock (for adjasting air flow)
3 . hole (for placing mice and checking salvent density) 4. out let

Fig. 1 Schema of exposure chamber with constant flow setted in the room controled temperature

1)を用い,トリクロルエチレンの発生は, diffusion 法の原理に従って行なった た清浄空気は発生瓶の中で diffusion によって ガス化され，暴露チャンバー内に供給される。 こうして, 暴露チャンバー内のガス濃度が500ppm に達した後，テフロン栓 3 をはずし，すばやく マウスを 4 匹入れ60分暴露した。なお，暴露中 はマウスに飳および水を与えなかった。

3．1）試料の調整；上述の方法で，トリク ロルエチレンをマウスに暴露した後, 暴露終了 直後, 30 分後, 60 分後, 120 分後に頸動脈切開に て採血後, 心藏, 肺臓, 肝臓, 㛑臓, 脾臓, 脳, 腹腔内脂肪，その他の組織を取り出し，冷生理 食塩水で洗浄, 重量測定後, homogenize し濃 度測定用試料とした。

2 ）試料中の溶剮濃度の分析：佐藤のガスク ロマトグラフバイアル平衡法6にによった。すなわ ち、あらかじめ硫酸アンモニウム $5 \mathrm{~g}$ を入れた

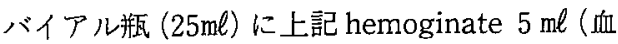
液は, 採血した $0.2 \mathrm{~m} \ell$ を蒸留水で希䣋した $5 \mathrm{~m} \ell$ と したもの)を加之, さらに, 内部標準液 $(1,1$, 2-トリクロルエタンをポリエチレングリコール 400 で水に暞濁させた） $1 \mathrm{m \ell}$ 加え，アルミ箔で
被ったゴム栓をし，さらにアルミキャップで密 封し $60^{\circ} \mathrm{C}$ の振恒温水槽に 30 分放置後, 気相 $2 \mathrm{~m} \ell$ をガスタイトシリンジでガスクロマトグラフィ 一に注入分析した。

また，検量線は，各正常組織 homoginate お よび希釈血液に，トリクロルエチレンおよび内 部標準夜を加え，よく擋挥した後，同様の方法 で分析して作成した。なお，ガスクロマトグラ フィーによる分析条件は以下のごとくである。

力 ラ ム: 充填剤 Benton 34 ステンレスカラム $3 \mathrm{~mm} \times 2 \mathrm{~m}$

カラム温度： $130^{\circ} \mathrm{C}$ ・

䇪素流量: $1.2 \mathrm{~kg} / \mathrm{cm}^{2}(40 \mathrm{~m} \ell / \mathrm{min})$ 水素活量: $0.6 \mathrm{~kg} / \mathrm{cm}^{2}(20 \mathrm{~m} \ell / \mathrm{min})$ 空気流量: $1.1 \mathrm{~kg} / \mathrm{cm}^{2}(300 \mathrm{~m} \ell / \mathrm{min})$ 機 器：日立063型 FID 付ガスクロマト グラフ

\section{結果}

1. 暴露直後の組織内濃度の経時変動

トリクロルエチレン500 ppmを60分吸入暴露後の 時間に伴う各臟器組織内濃度の変化を（Table 1) 片效数グラフで（Fig. 2) に表わす. 
Table 1 Concentration of trichloroethylene in tissues and blood after exposure. (mean $\pm \mathrm{SEM}$ )

\begin{tabular}{|c|c|c|c|c|}
\hline time & 0 minutes & 30 minutes & 60 minutes & 120 minutes \\
\hline conc. & $\mu g / g$ & $\mu \mathrm{gg} / \mathrm{g}$ & $\mu \mathrm{g} / \mathrm{g}$ & $\mu g / \mathrm{g}$ \\
\hline Heart & $21.36 \pm 2.26$ & $15.09 \pm 1.89$ & $12.68 \pm 1.82$ & $12.40 \pm 1.84$ \\
\hline Lungs & $28.25 \pm 10.88$ & $11.09 \pm 2.27$ & $11.75 \pm 1.29$ & $10.20 \pm 2.11$ \\
\hline Liver & $24.03 \pm 2.95$ & $15.04 \pm 2.68$ & $13.19 \pm 2.36$ & $10.19 \pm 2.73$ \\
\hline Kidneys & $34.59 \pm 7.11$ & $17.04 \pm 0.66$ & $13.85 \pm 1.19$ & $10.59 \pm 1.63$ \\
\hline Spleen & $23.94 \pm 6.12$ & $12.24 \pm 0.94$ & $12.93 \pm 1.19$ & $9.44 \pm 1.68$ \\
\hline Brain & $9.87 \pm 0.55$ & $8.56 \pm 0.93$ & $8.01 \pm 0.95$ & $7.76 \pm 1.01$ \\
\hline G. I. Tract & $12.34 \pm 2.23$ & $10.02 \pm 0.79$ & $9.17 \pm 1.46$ & $7.11 \pm 1.98$ \\
\hline Adip. tiss & $463.11 \pm 21.90$ & $261.73 \pm 37.25$ & $252.65 \pm 35.87$ & $210.80 \pm 25.89$ \\
\hline Blood & $15.80 \pm 2.21$ & $5.10 \pm 0.18$ & $3.94 \pm 0.51$ & $3.36 \pm 0.03$ \\
\hline Others & $78.57 \pm 8.29$ & $30.01 \pm 4.35$ & $33.65 \pm 7.71$ & $22.37 \pm 2.63$ \\
\hline
\end{tabular}
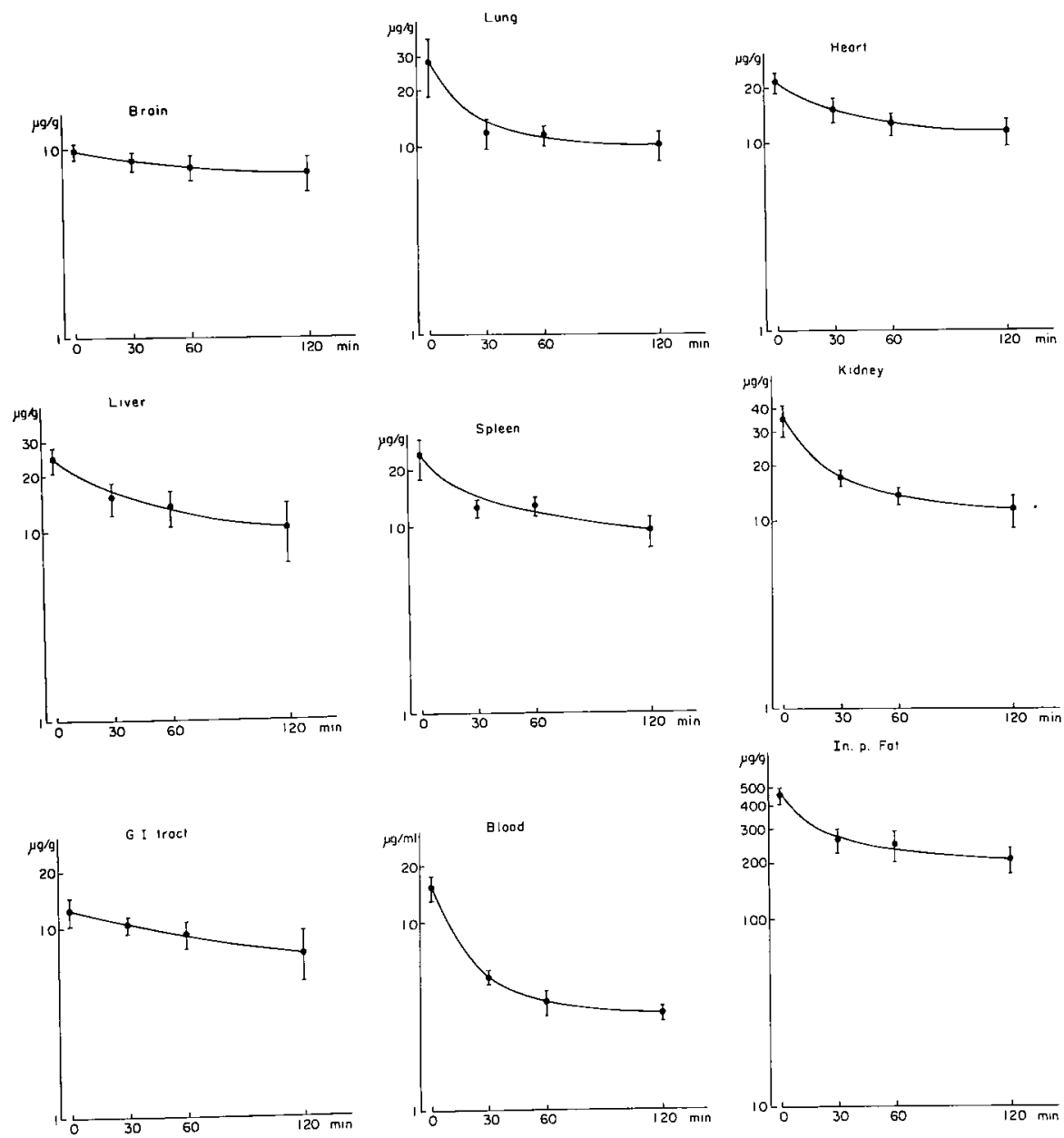

Fig. 2 Time-course of trichloroethylene concentration in tissues and blood after exposure. The vertical lines represent the mean $\pm S E M$. 
即ち，吸入終了直後の組織中の濃度は，腹腔 内脂肪が最も高く，以下，堅，肺，肝，脾，心， 消化管・脳の順であった。

組織内の濃度の減少速度が比較的速いものは, 血液, 腎, 肺であり，逆に遅いものは脳，消化 管，心，腹些内脂肪であった。そして，吸入後 の濃度が吸入直後の $1 / 2$ になるのに要する時間 (臟器の生物学的半減期) は, 血液, 肺, 腎が 約30分以内であるのに対し，脳，心，消化管は 2 時間以上であった。

\section{2、臟器からの消失時間の分析}

肺，消化管，脾臓は one compartment model であり, 血液, 心臓, 筒臓, 肝臟では two compartment modle であった. Fig. 3に, トリクロル エチレンの血液に扔ける消失曲線を示した。こ のようにほとんどの臟器組織における消失曲線 は，長短の半減期を有する 2 個の指数関数曲線 を合成した物であることが認められた。従って， 残差法》に扔计る第 1 相の半減期を Table 2 の 上段に示した。半減期は， $\mathrm{y}=\mathrm{ae}^{-\mathrm{k}}$ における消 失係数 $\mathrm{k}$ により $\mathrm{t}_{1 / 2}=0.693 \times 1 / \mathrm{k}$ の式で算 出した，さらに，Table $2 の$ 下段には，残差法 であてはめ, 近似值に計算した半減期を示した。 この值は，実測值を用いて罒示した Fig. 3 によ
ク概算した半減期と大差は認められなかった。 半滅期としては便宜上, 最高濃度の $1 / 2$ 濃度を 示す時間とした。

\section{3. 各臓器組織残留量と分布比の経時変化}

トリクロルエチレン 500 ppmを60分吸入暴露後, 時間に伴う各臟器内分布比（\%) を臓器内量の 和を $1,000 \%$ として算出した。㿽成績を Table 3 に示す. 60 分吸入暴露の直後において，特に 臓器組織内分布比（\%) は，肝 $(38.73 \%)$ ，消 化管 $(48.79 \%)$ ，血液 $(38.67 \%)$ であった，次

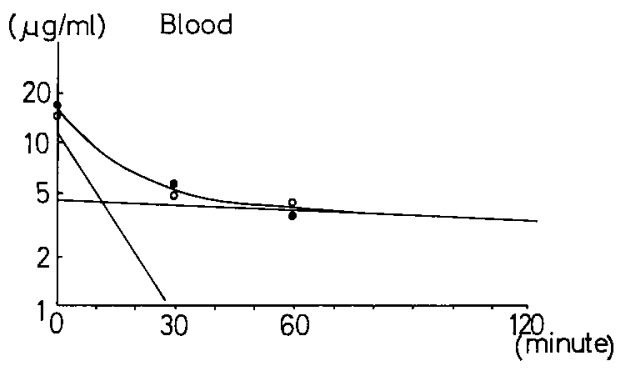

Fig. 3 Decreased in concentration of trichloroetylene in the blood of mice exposed to $500 \mathrm{ppm}$ of trichloroethylene. Comparison between theoretical curve and experimental curve. ( $\bigcirc$ theoretical value, actual value)

Table 2 Equation for elimination curve of trichloroethylene in the organs by the method of residue and of least squares

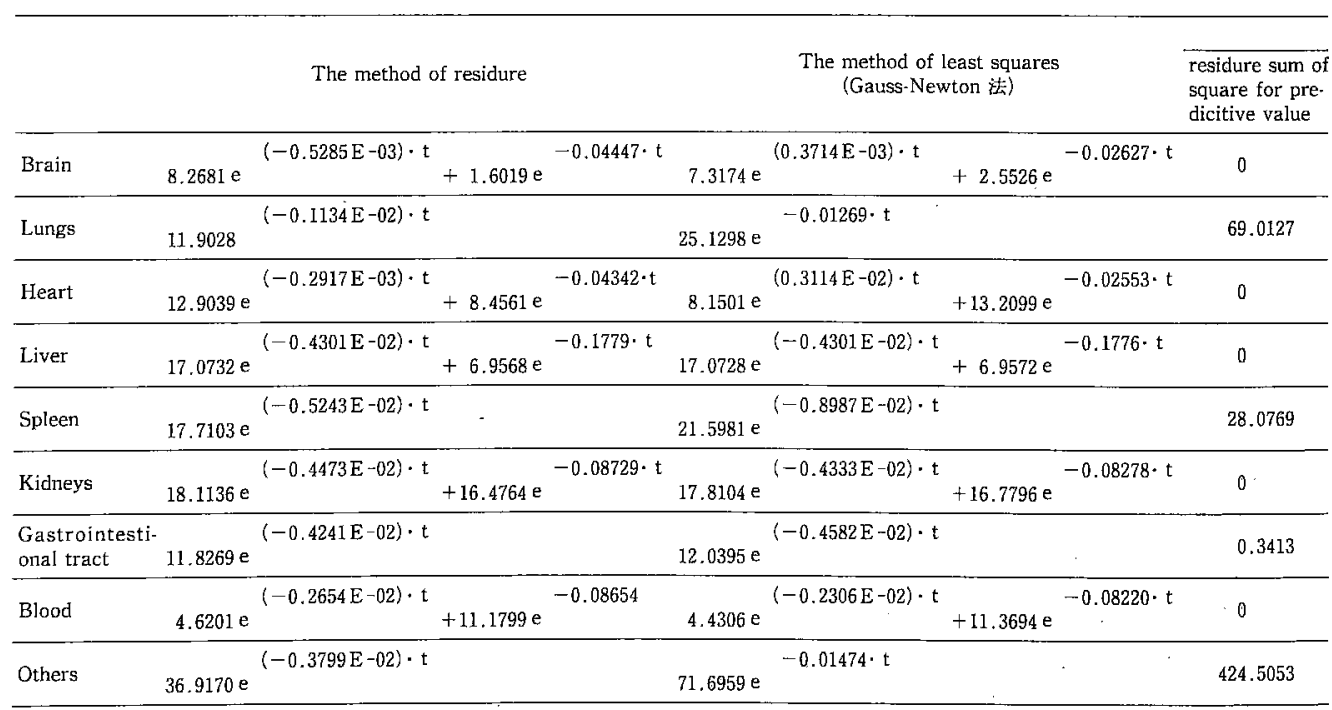

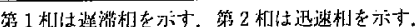


Table 3 Distribution of trichloroethylene in tissues and blood after exposure

\begin{tabular}{|c|c|c|c|c|c|c|c|c|}
\hline \multirow{2}{*}{$\frac{\text { time }}{\text { unit }}$} & \multicolumn{2}{|c|}{0 minutes } & \multicolumn{2}{|c|}{30 minutes } & \multicolumn{2}{|c|}{60 minutes } & \multicolumn{2}{|c|}{120 minutes } \\
\hline & $\mu g$ & $\%$ & $\mu g$ & $\%$ & $\mu g$ & \% & $\mu g$ & $\%$ \\
\hline Heart & $1.90 \pm 0.16$ & 2.87 & $1.30 \pm 0.14$ & 3.35 & $1.11 \pm 0.16$ & 3.77 & $1.21 \pm 0.20$ & 6.49 \\
\hline Lungs & $5.15 \pm 2.06$ & 7.78 & $2.66 \pm 0.57$ & 6.85 & $2.04 \pm 0.15$ & 6.93 & $2.15 \pm 0.47$ & 11.44 \\
\hline Liver & $25.63 \pm 2.89$ & 38.73 & $15.24 \pm 2.83$ & 39.23 & $13.29 \pm 2.64$ & 45.12 & $9.59 \pm 3.07$ & 51.05 \\
\hline Kidneys & $8.49 \pm 1.69$ & 12.83 & $4.34 \pm 0.12$ & 11.17 & $3.23 \pm 0.34$ & 10.96 & $2.9 \pm 0.39$ & 13.79 \\
\hline Spleen & $2.33 \pm 0.36$ & 3.52 & $1.27 \pm 0.10$ & 3,27 & $1.17 \pm 0.18$ & 3.97 & $1.05 \pm 0.19$ & 5.59 \\
\hline Brain & $4.49 \pm 0.31$ & 6.78 & $3.56 \pm 0.32$ & 9.16 & $3.58 \pm 0.47$ & 12.15 & $3.44 \pm 0.42$ & 18.31 \\
\hline G. I. Tract* & $32.29 \pm 4.49$ & 48.79 & $27.51 \pm 1.12$ & 70.82 & $25.97 \pm 3.72$ & 88.16 & $20.22 \pm 5.28$ & 107.63 \\
\hline Blood & $25.59 \pm 3.57$ & 38.67 & $8.26 \pm 0.29$ & 21.26 & $6.38 \pm 0.82$ & 21.66 & $5.44 \pm 0.05$ & 28.96 \\
\hline Others** & $565.29 \pm 59.67$ & 823.97 & $329.56 \pm 36.14$ & 848.35 & $242.13 \pm 55.51$ & 821.95 & $146.59 \pm 16.42$ & 780.27 \\
\hline Total & $661.78 \pm 72.67$ & $1,000.00$ & $388.47 \pm 41.82$ & $1,000.00$ & $294.58 \pm 63.50$ & $1,000.00$ & $187.87 \pm 25.63$ & $1,000.00$ \\
\hline
\end{tabular}

いで30分以後において, 消化管, 肝臟のトリク ロルエチレン残留量は時間に従って徐々に減少 した。

分布比は 120 分後には直後の約 2 倍に達した。 血液の分布比は（体重 $1 / 13$ として算出）30分後 に残留量, 分布比が急に減少し, その後は血中 濃度は横ばい状態となった。徒って吸入暴露直 後の分布比が少なかったのは，心臟 $(2.87 \%$ \%)， 脾蔵 $(3.52 \%)$, 䐘 $(6.78 \%)$ であり, この中で, 心，脳は30分以後において分布比が増大する傾 向が強く 120 分後には約 2.5 倍に達した。

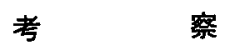

作業現場において䓏気の吸入による経気道的 侵入が，有機溶片の主な侵入経路であることは 多くの動物抢よび人体蒸気暴露実験報告により 確認されている．体内に吸入された有機溶剤は 血液溶解度に従って, 肺胞より血液中に取り込 まれ各組織に分布される.

有機溶剂の投与後の臟器濃度・藏器内分布の 変動については,トリクロルエタンにおける高 原1),クロルベンゼンにおける嶋田 ${ }^{2)}$, トルエン に扔ける神谷引の報告がある。

今回著者は, マウスにトリクロルエチレン吸 入暴露後 2 時間までの臟器のトリクロルエチレ ン濃度について測定を行なった. 暴露直後の濃 度については, 腎臓, 肝藏, 心臓に高く, 脳に 低い濃度を示した。暴露 2 時間後の臟器中濃度
を暴露直後の濃度で除した比で比較すると, 睬 $79 \%$ ，心臓 $58 \%$ ，肝臟 $42 \% ，$ 肺 $36 \%$ ，腎臓 $31 \%$ であり脳についで心臓の濃度比が高く，腎臓の 濃度が低い。

マウスにトリクロルエチレン吸入暴露後の蔵 器中濃度の減衰については迅速相抢よび遅滞相 の Two compartment model の場合は,

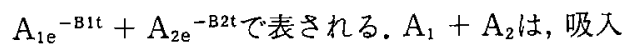
直後の濃度を示し, その値は腎臓, 肝臓, 心蔵, 血液, 脳の順に高い.また, 迅速相および遅滞 相の排泄係数を示す $\mathrm{B}_{1}$ および $\mathrm{B}_{2}$ について比較 した場合には, 脳, 心臟はいずれも他の臓器よ ク低く,これらの臓器では, 有機溶剂が蓄積し やすい傾向にある.

また, 藏器の分布比の変動を(2 時間内の臓 器内分布比率/直後の臟器内分布比率)の比より, 心臓と脳の分布比の減少度を比べると腎臓, 肝 臓の分布比の減少度は高く, 分布による変動成 績はほほ濃度によるそれと一致を示した。

\section{結論}

dd 系จウスにトリクロルエチレン $500 \mathrm{ppm}$ の蒸 気を60分暴露させた後, 2 時間藏器分布を測定 し，以下の成績を得た.

1. 暴露直後の藏器中のトリクロルエチレン 浱度は, 脂肪組織, 監, 肺, 肝の順に高かった。

2. 暴露後,トリクロルエチレン濃度の減少 傾向の大きい臓器は, 血液, 腎臟, 肺, 脳, 心 
臟の順であった。

3. 生物学的半減期は, 肺, 消化管, 脾蔵の 值については one compartment model, 血液, 心臓，腎臓，肝臓の値については two compartment model の傾向を示した。血液, 督, 肺,
脾藏は30分以下であり，脳，消化管，心臓は 2 時間以上であった。即ち, 脳以下の藏器群は, 肺以上の臟器群に比べて時間に対する濃度の低 下が漣かった。

\section{文献}

1）高原和夫：trichloroethane 中毒に関する実験的研究 第 1 編 1，1，1-或は 1, 1,2-trichloroethana 投 与後の臟器組織内分布. 岡山医誌 (1986) 98, 11-12.

2) 高原和夫：trichloroethana 中毒に関する実験的研究 第 3 編 1, 1, 1 或は 1, 1,2-trichloroethana, carbon, tetrachloride などの塩素系有機溶剤投与後の肝 ATP, triglyceride などの変動. 岡山医誌 (1986) 98, 11-12.

3 ）嶋田義弘：モノクロロペンゼン中毒に関する研究 第2 編 モノクロロベンゼン暴露後のマウス臟器内分布. 阔山医誌（1986）100, 135-146.

4）神谷二郎：芳香族有機溶剤の生体内運命 第 4 編 マウスに投与した放射性標識トルエンの贜器分布及U゙呼 気中排泄. 岡山医誌 (1986) 99，1651-1657.

5 ）野崎恒右：吸入物質供給系操作の実際；環境大気污染のための吸入実験。河合清之，横山栄二編，ソフトサ イエンス社, 東京 (1980) pp 77-100.

6) A Sato, T Nakajima and Y Fujiwara : Determination of benzen and toluen in blood by means of a syringe-equilibration method uning a small amount of blood. Br J Ind Med (1975) 32, 210-214.

7 ) 山岡 清, 谷川原祐介：非線形最小二乗法による曲線のあてはめ; マイコンによる薬物速度論入門, 南山堂, 東京 (1983) pp 33-72. 


\author{
Studies on the trichloroethylene metabolism \\ and storage of urinary trichloroethylene metabolites \\ Part 2. Organ distribution of trichloroethylene \\ in the mice after exposure to trichloroethylene \\ Tatsuya Aтomura \\ Department of Public Health, \\ Okayama Undversity Medical School, \\ Okayama 700, Japan \\ (Director : Prof. M. Ogata)
}

The organ distribution and the concentration of trichloroethylene were defermined in mice exposed to trichloroethylene 500ppm.

Organ distribution of trichloroethylene was in the descending order of adipose tissue, such as the kidneys, the lung, the liver, the spleen, the heart, the digestiveorgan and brain. The concentration of trichloroethylene in the organ decreased in descending order of the blood $>$ the kidneys $>$ the brain $>$ the heart. Biological half lif in the blood, the lungs and the kidney was within 30 minutes and that in the brain, the stomach and the heart over 2 hours. 